\title{
Sık görülen iskelet diplazileri ve hareket analizi özellikleri
}

\author{
Common skeletal dysplasias and their gait patterns
}

\author{
İlhan Bayhan, William G. Mackenzie
}

Nemours Alfred I. duPont Hospital for Children, Wilmington, DE, USA

\begin{abstract}
İskelet displazileri, kemik ve kıkırdağın gelişim anomalileri ile karakterize bir hastalıklar grubudur. Genellikle orantısız kısalık ile ilişkilidir ve bu geniş heterojen grubun doğurduğu hastalağın şiddeti erken osteoartritten perinatal ölüme kadar değişkenlik gösterebilir. İskelet diplazilerinin tedavisinde ortopedi uzmanlarının rolü, mevcut fonksiyonun korunması veya iyileştirilmesi ve ilerleyen dönemlerde gelişebilecek kısıtlılıkların önüne geçmek olmalıdır. İskelet displazisi olan olguların alt ekstremite dizilim bozukluklarının değerlendirilmesinde koronal ve sagittal plan deformiteleri için yüklenme altında çekilen bacak uzunluk grafileri ve torsiyonel deformiteler için bilgisayarlı tomografi geleneksel yöntemlerdir. Üç boyutlu hareket analizi ile hareketin dinamik değerlendirilmesi, iskelet displazisi olan olguların tedavi ve takibinde yüklenme altında tüm planlardaki deformiteler konusunda hassas bilgi vermesi ile, umut vaat eden bir gelişme olarak gözlenmektedir.
\end{abstract}

Anahtar sözcükler: kemik displazileri; yürüyüş analizi; deformite

steokondral displaziler, kemik ve kıkırdak gelişimi ve büyümesini etkileyen nadir hastalıklar grubudur. Bu hastalıkların patogenezi çok çeşitlilik göstermektedir. İskeletin yapısal molekülerinin hücre içi veya dışı işlenmesinde veya transkripsiyonundaki değişiklikler sonucu oluşabileceği gibi iskelet diferansiyasyon veya proliferasyon basamaklarının reseptör veya sinyal transduksiyonundaki değişiklikler sonucu da oluşabilir.

İskelet displazilerinin geleneksel olarak sınıflandırması, Uluslararası Osteokondroplazi Sınıflandırması'nda olduğu gibi, kemik tutulum tipine göre oluşturulmuştur. ${ }^{[1,2]}$ Son zamanlarda bu hastalıkların gruplandırılması, etkilenen bölgenin bilindiği olgularda spesifik etken gendeki defekte göre yapılmaktadır. ${ }^{[1]}$ Günümüze kadar dört yüzün üzerinde iskelet displazisi tipi tanımlanmıştır.

İskelet diplazilerinin tedavisinde ortopedi uzmanlarının rolü, mevcut fonksiyonun korunması veya
Skeletal dysplasias are disorders characterized by developmental abnormalities of the bone and cartilage. They are usually associated with disproportionate short stature and this large heterogenous group can range in severity from early osteoarthritis to perinethal lethality. The goal of orthopedic surgeon caring for a person with skeletal dysplasia should be to preserve or improve function and prevention of future limitations. Traditional evaluation tools for the lower extremity malalignments in patients with skeletal dysplasia are weight-bearing orthoroentgenograms for the coronal and sagittal plan deformities and CT for the torsional deformities. Dynamic evaluation of gait with 3D gait analysis seems to be promising improvement in the treatment and follow-up of bone deformities in skeletal dysplasia patients by giving accurate information about each plan deformities under loading.

Key words: bone dysplasias; gait analysis; deformity

iyileştirilmesi ve ilerleyen dönemlerde gelişebilecek kısıtlııkların önüne geçmek olmalıdır.

İskelet displazisi olan olgularda ayakta yük vererek çekilen alt ekstremite uzunluk grafileri, alt ekstremite deformitelerinin analizinde ve ameliyat öncesi planlamada sıklıkla kullanılmaktadır. Fakat bu hastalarda sıklıkla gözlenen eklem laksitesi ve diğer eklem anomalileri, yürüyüş ve yüklenme esnasında dizilim değişiklikliğine neden olmaktadır. Hareket analizi, dinamik bir inceleme sağlayarak bu hastaların daha ayrıntılı değerlendirilmesinde yardımcı olur. Ayrıca, hareket analizi, torsiyonel deformitelerin yük vermeden tomografi eşliğinde yapılan fonksiyonel değerlendirmeleri yerine, yüklenme sırasında oluşan değişikliklerini de ölçmede yardımcı olmaktadır. ${ }^{[3]}$

Bu çalışmada sık görülen iskelet displazileri ve onların alt ekstremite dinamik hareket analizi özellikleri yorumlanmıştır.

- Illetişim adresi: Illhan Bayhan, 1600 Rockland Road, Wilmington DE, USA

Tel: +1 302 - 3324721 e-posta: ilhanbayhan@hotmail.com

- Gelis tarihi: 23 Temmuz 2014 Kabul tarihi: 23 Temmuz 2014 


\section{AKONDROPLAZi}

Akondroplazi, enkondral ossifikasyon bozukluğu olup, 25.000 doğumda bir görülen en sık iskelet displazisi tipidir. ${ }^{[1,4,5]}$ Dördüncü kromozomun kısa kolundaki FGFR 3 geninin kodlanmasındaki mutasyondan kaynaklanmaktadır. Akondroplazi otozomal dominant geçişli bir rahatsızlık olmasında rağmen $\% 80$ olgu sporadikdir. ${ }^{[1,6]}$

En belirgin kısalık femur ve humerusta oluşarak, rizomelik tipte cücelik gözlenmesine neden olur. ${ }^{[1,7]}$ Omurgada, torakolomber bileşkede kifoz yaygın olup, 1-2 yaş arasında sıklıkla gözlenir. Birçok olguda yürümenin başlaması ile kifoz düzelme göstermektedir; fakat yürüme, akondroplazili olgularda sıklıkla gecikmektedir. Kifozun düzelmesi ile birlikte lomber lordoz progresyon gösterebilir. Omurganın ilerleyen takiplerinde, erken çocukluk döneminde foramen magnum stenozu ve ileri yaşlarda spinal stenoz açısından dikkatli olunmalıdır. Gövde yüksekliği normal sınırlarda veya normalin bir miktar altındadır. Ayak bileği ve dizin morfolojisinden kaynaklı alt ekstremitede sıklıkla varus dizlimi gözlense de, nadiren valgus dizilimi de gözlenebilir (Şekil 1). Genu varuma büyük oranda internal tibial torsiyon eşlik eder. Tipik olarak ayak bileği ve diz ekleminde de sıklıkla eklem laksisitesi gözlenmesine rağmen bu olgularda prematüre artrit nadiren gelişir. ${ }^{[1]}$

İnan ve arkadaşları Akondroplazili olguların alt ekstremite dinamik dizilimini incelediği çalışmalarında normal popülasyona göre adım mesafelerinin kısa ve yürüyüş hızının yavaş olduğunu gözlemlemişlerdir. Olguların boy ve ağırlık farklılıklarından dolayı gözlemsel sonuçlarda büyük farklılık olduğu saptanmıştır. Adım uzunluğunun genişletilmesi ve normale yaklaştııılmaya çalışılması sonucunda pelvik rotasyonun arttığı saptanmıştır. Ayrıca lomber lordozun artışına sekonder, anterior pelvik tiltin arttı̆̆ı da gözlemlenmiştir (Şekil 2. a, b). ${ }^{[8]}$

Kalça kinematikleri, artmış pelvik anterior tilt nedeni ile kısıtlı kalça ekstansiyonunu yansıtması dışında normal popülasyon ile uyumlu bulunmuştur. Kalça rotasyonu da normal popülasyonla uyumlu olmasına rağmen değişkenlik göstermiştir. Koronal ve transvers planda yapılan hareket analizi grafikleri, dizde varus dizilimi ve değişken oranlarda tibial internal torsiyonun olduğunu göstermiştir. Sagittal plandaki dizin fleksiyon grafiklerinde, topuk temas, yüklenme esnasında ve salınım fazında normal popülasyonla uyumluluk bulunmuştur. Dizin varus dizilimine sekonder olarak, pedobarografik incelemede ayağın artmış varus basıncı olduğu gözlenmiştir (Şekil 3).

Dizin kinetik analizinin, normal popülasyona göre artmış internal valgus momenti (eksternal varus momenti) yansıttığı ortaya konmuştur (Şekil 4). Artmış diz valgus momentine rağmen, benzer boydaki sağlıklı olgulara kıyasla düşük vücut kitle indeksi ve eklem morfolojisindeki farklılıklar sayesinde, akondroplazili olguların bu moment değişikliğini daha iyi tolere ettiği ve diz osteoartritinin gelişmediği sıklıkla gözlenmektedir.

\section{PSÖDOAKONDROPLAZi}

Adlandırma olarak akondroplazi ile benzerlik gösterse de, fenotipik ve genotipik olarak farklı bir hastalık grubudur. Psödoakondroplazi, COMP (Cartilage Oligomeric Matrix Protein) proteinindeki bir mutasyondan kaynaklanmaktadır. ${ }^{[1,9,10]}$ Bu protein mutasyonu bazı multipl epifizyel displazi tiplerindeki mutasyon ile benzerlik göstermektedir. Psödoakondroplazili olguların kondrositlerinde, endoplazmik retinakulumda COMP proteini birikimine bağı lamellar inklüzyon cisimcikleri gözlenmektedir.

Pseödokondroplazi, yüz yapısının normal olması ve erken çocukluk döneminde herhangi bir bulgu vermemesi nedeni ile sıklıkla geç fark edilir. Hastalık sıklıkla 2-4 yaş arasında belirti vermeye başlar.

Akondroplazide görüldüğü gibi psödokondrolpazili olgularda da kısalık rizomelik tiptedir. Bu olgularda genu varum, genu valgum ve windswept deformitesi gibi çeşitli eklem dizilim bozuklukları gözlenebilir. Sıklıkla eklem laksisitesi eşlik eder. Erken yaşlarda kalça, diz ve ayak bileği ekleminde artroz gözlenebilir (Şekil 5).

Gaebe ve arkadaşları yaptıkları bir çalışmada, 12 psödoakondroplazi olgusunun hareket analizlerini değerlendirilmişlerdir. Kinematik analizde gövde salınımının

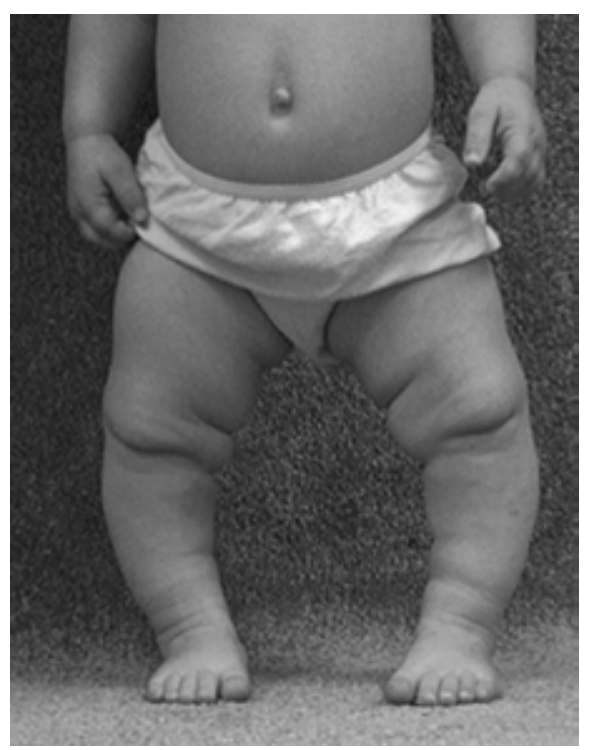

Şekil 1. Üç yaşında Akondroplazili bir olguda genu varum ve internal tibial torisyon. 


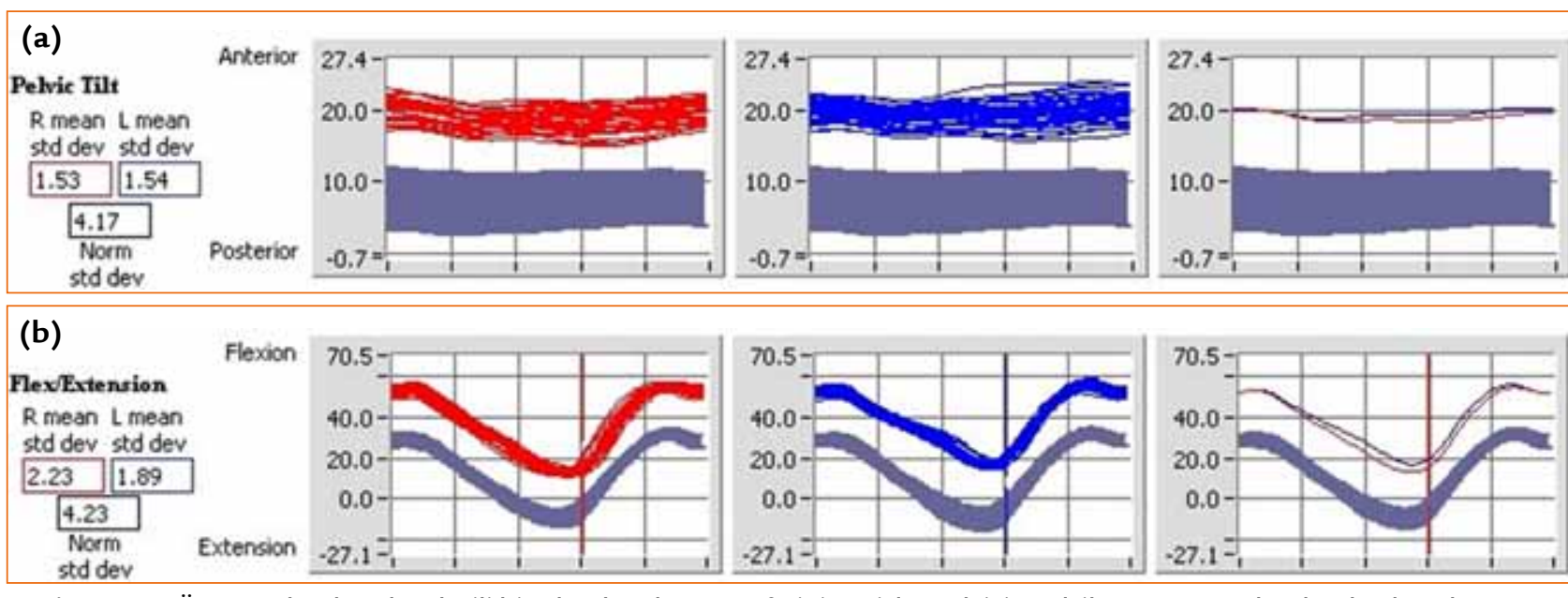

Şekil 2. a, b. Üç yaşında Akondroplazili bir olguda adım mesafesini genişletmek için pelvik rotasyon ve lomber lordozu kompanse etmek için pelvik tiltte artış gözleniyor (a). Aynı olgunun kalça fleksiyon ve ekstansiyon grafilerinde lomber lordozun kompanzasyonu için artmış kalça fleksiyonu gözlenmektedir (b).
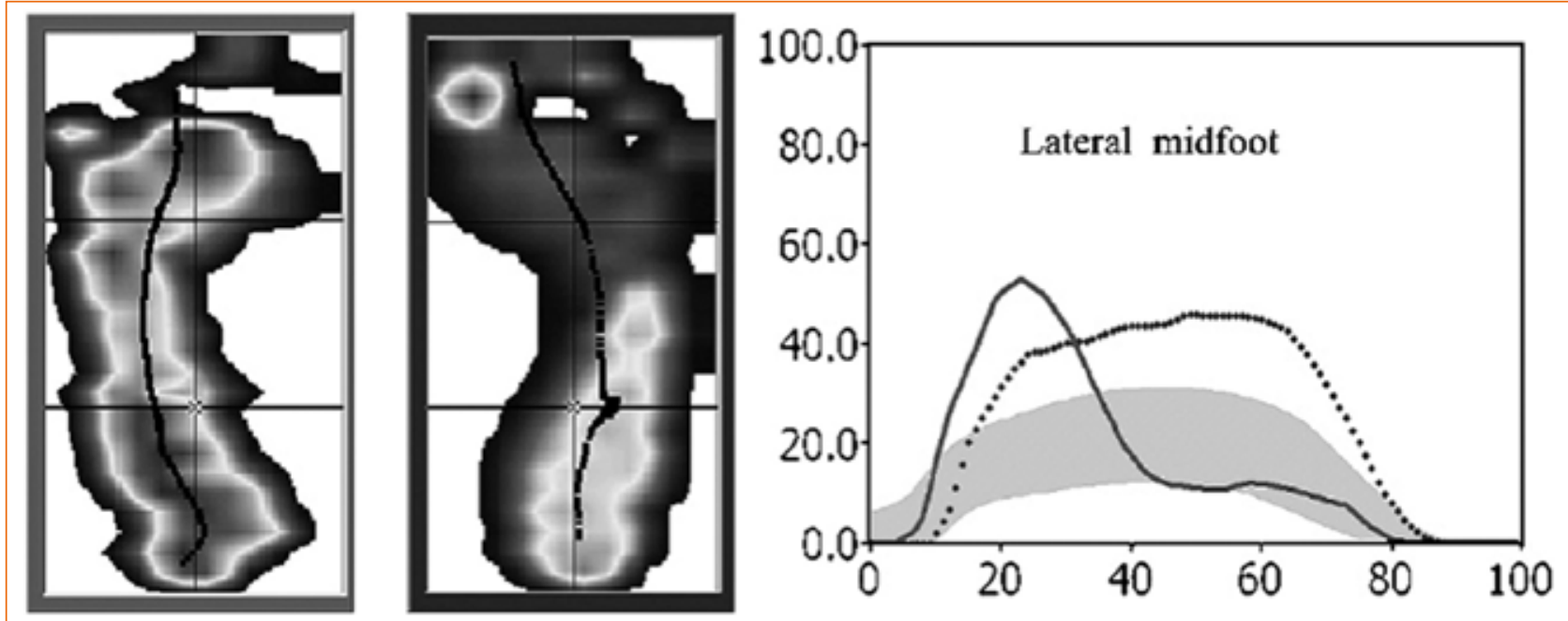

Şekil 3. Beş yaşında Akondroplazili bir olguda varus ayak basıncı. Dizden kaynaklanan varus ayağın lateral bölümünde basınç artışına neden olmaktadır.

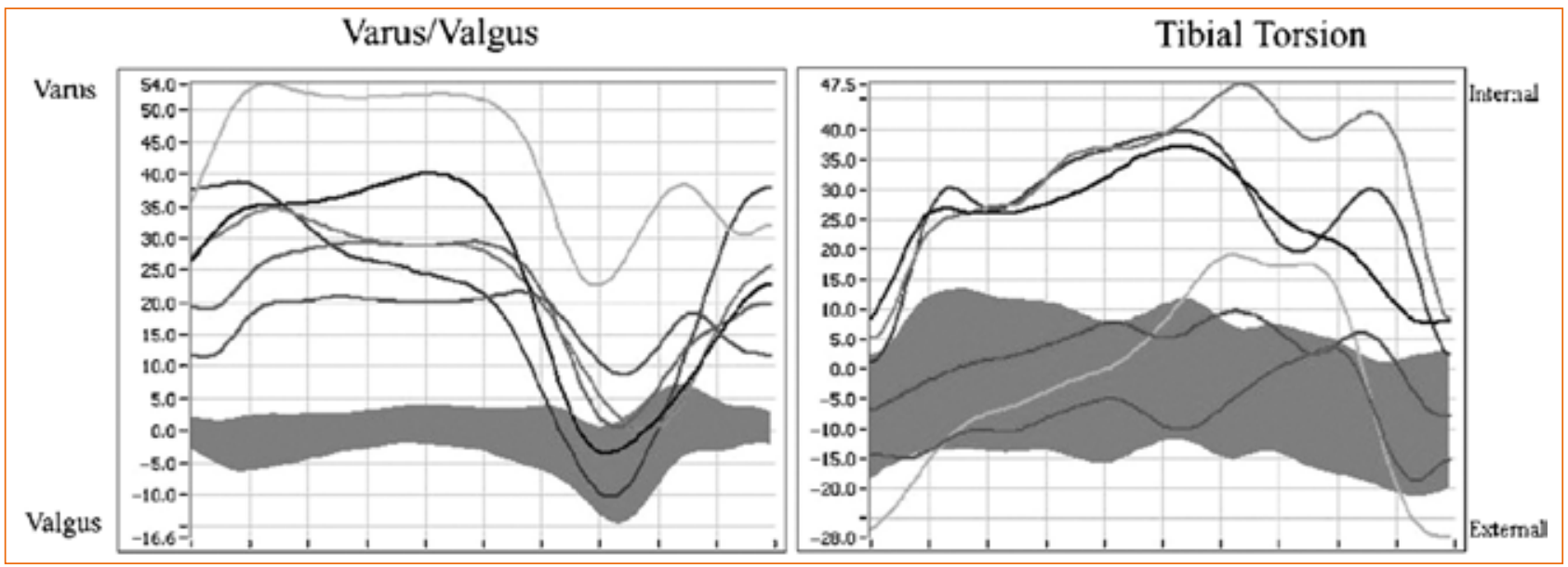

Şekil 4. Üç, 15 ve 16 yaşlarında akondroplazili üç olgunun diz varus ve tibial torsiyon grafileri. Diz eklemindeki eklem laksisitesi kaynaklı basma fazında varus deformitesinde artış ve salınım fazındaki düzelme gözlenmektedir. Benzer bulgular tibial torsiyonda da izlenmektedir. 
ve pelvik tiltin arttığı ve adım mesafesinin normal popülasyona göre azaldığı gözlenmiştir. Bu olguların diz dizilimleri büyük oranda değişkenlik göstermesine rağmen varus diziliminin baskın olduğu saptanmıştır. $\left(21,5^{\circ}\right.$ valgus ile $40^{\circ}$ arası varus, ort. $\left.13.5^{\circ} \pm 13.1^{\circ}\right)$.
Tibial torsiyonun, üç olgu hariç internal olduğu gözlenmiştir ( $6^{\circ}$ eksternal, $54^{\circ}$ internal torsiyon). [11]

Kinetik analiz, kinematik analiz ile uyumlu olarak değişkenlik gösterse de, dizde valgus momentinin baskın olduğu gözlenmiştir (Şekil 6,7 ).

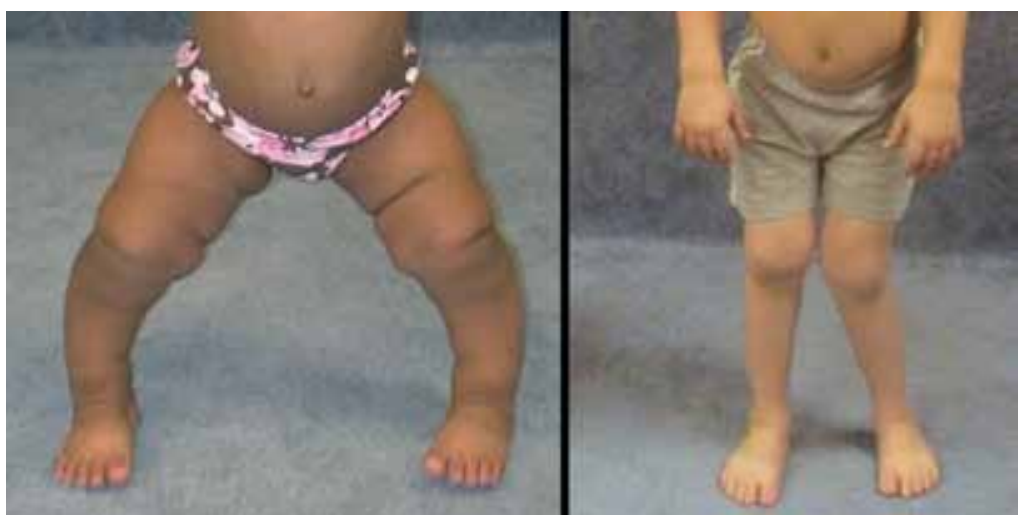

Şekil 5. Psödoakondroplazili olgularda gözlenen alt ekstremite deformiteleri.

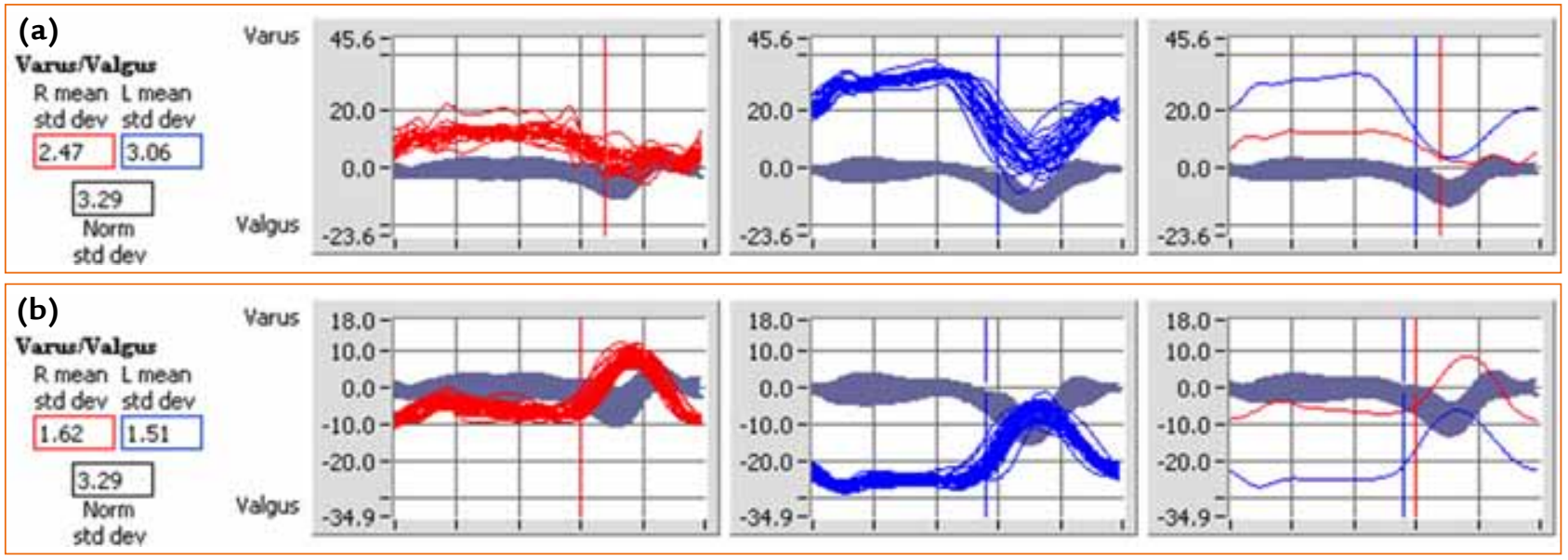

Şekil 6. a, b. Dinamik varus ve valgus diz kinematik grafikleri: Varus açılanma (a) ve valgus açılanma (b). Her iki olgunun sol alt ekstremitesinin (orta bölümdeki grafik) daha şiddetli tutulduğu görülmektedir.

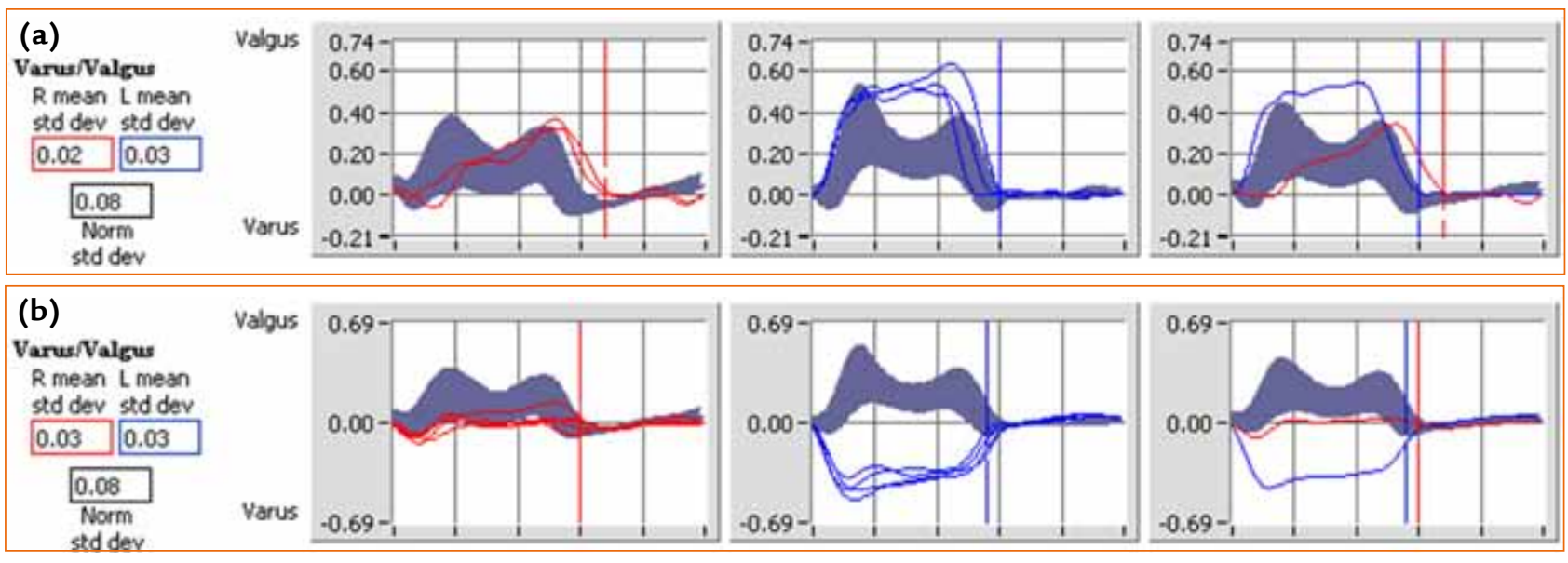

Şekil 7. a, b. Dinamik varus ve valgus diz kinetik grafikleri: her iki olgunun sol alt ekstremitesinde (orta bölümdeki grafik) varus açılanmasından kaynaklı artmış valgus internal momenti (a) ve valgus açılanmasından kaynaklı varus internal momenti (b) görülmektedir. 


\section{DIASTROFIK DISPLAZi}

Diastrofik displazi, 5. kromozomda yer alan kıkırdak matriksindeki proteoglikanların sülfatlanmasını sağlayan sülfat transport genindeki mutasyonlar sonucu oluşur.

Ekstremitelerde rizomelik tipte kısalık gözlenir. Servikal vertebradan ayağa kadar yaygın iskelet anomalileri saptanabilir. Servikal vertebranın alt segmentleri sıklıkla bifiddir; $1 / 3-1 / 2$ arası olguda servikal kifoz gözlenebilir. $1 / 3$ olguda skolyoz gelişebilir ve üç yaş altında başlayan olgularda daha ağır seyredebilir. Alt ekstemite cerrahisi uygulanmadan önce omurganın stabil olduğu mutlaka kontrol edilmelidir. Dirsek ekleminde radius başında ve omuzda subluksasyon gözlenebilir. Neonatal kalça çıkığı saptanabilir. Proksimal interfalangeal eklemlerde sıklıkla füzyon gözlenir (simfalangizm). Kalça ekleminde çoğunlukla fleksiyon kontraktürü oluşur ve proksimal femur epifizinde progresif deformasyon gözlenebilir. Diz ekleminde de ligamentöz kontraktür ve epifizyel deformasyon sonucu fleksiyon kontraktürü yaygındır. Artmış genu valgum ve eşlik eden deformiteler sonucunda, $1 / 4$ olguda patella çıkığı gözlenir. ${ }^{[1,12]}$ Dejeneratif eklem hastalıkları, sıklıkla erken erişkin dönemde gelişir.

Diastrofik displazideki ayak deformitesi genellikle pes ekinovarus deformitesi ile özdeşleştirilir; fakat belirgin farklılıklar içerir. ${ }^{[1,13]}$ Ekin deformitesi diastrofik displazili olgularda daha belirgin olup, navikula talusun lateralinde yer alır. Ayak başparmağı, elde olduğu gibi, otostopçu parmağı deformitesini taklit eder. Ayak deformitesi, kemik malformasyonları ve eklem kontraktürleri nedeni ile oldukca rijiddir (Şekil 8,9 ).

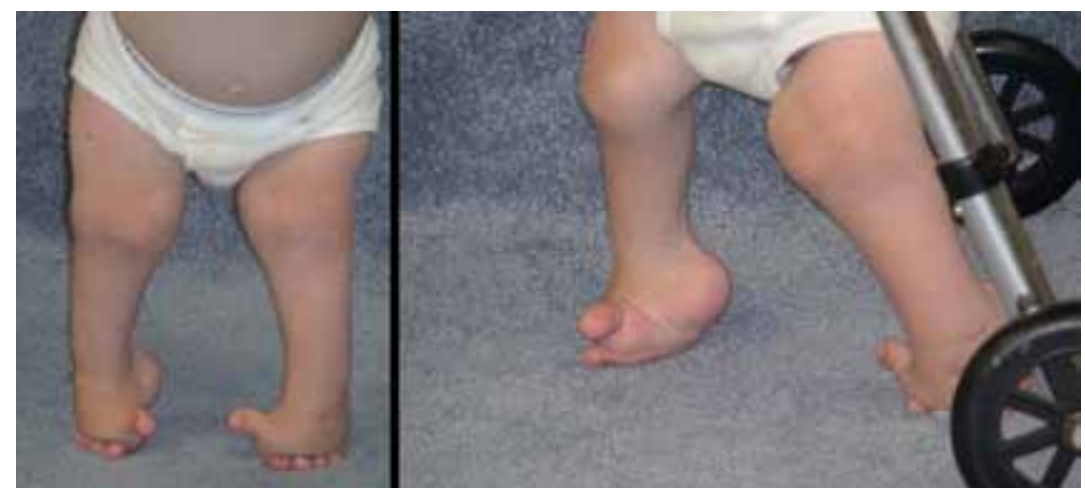

Şekil 8. Diastrofik displazide alt ekstremite dizilimi.
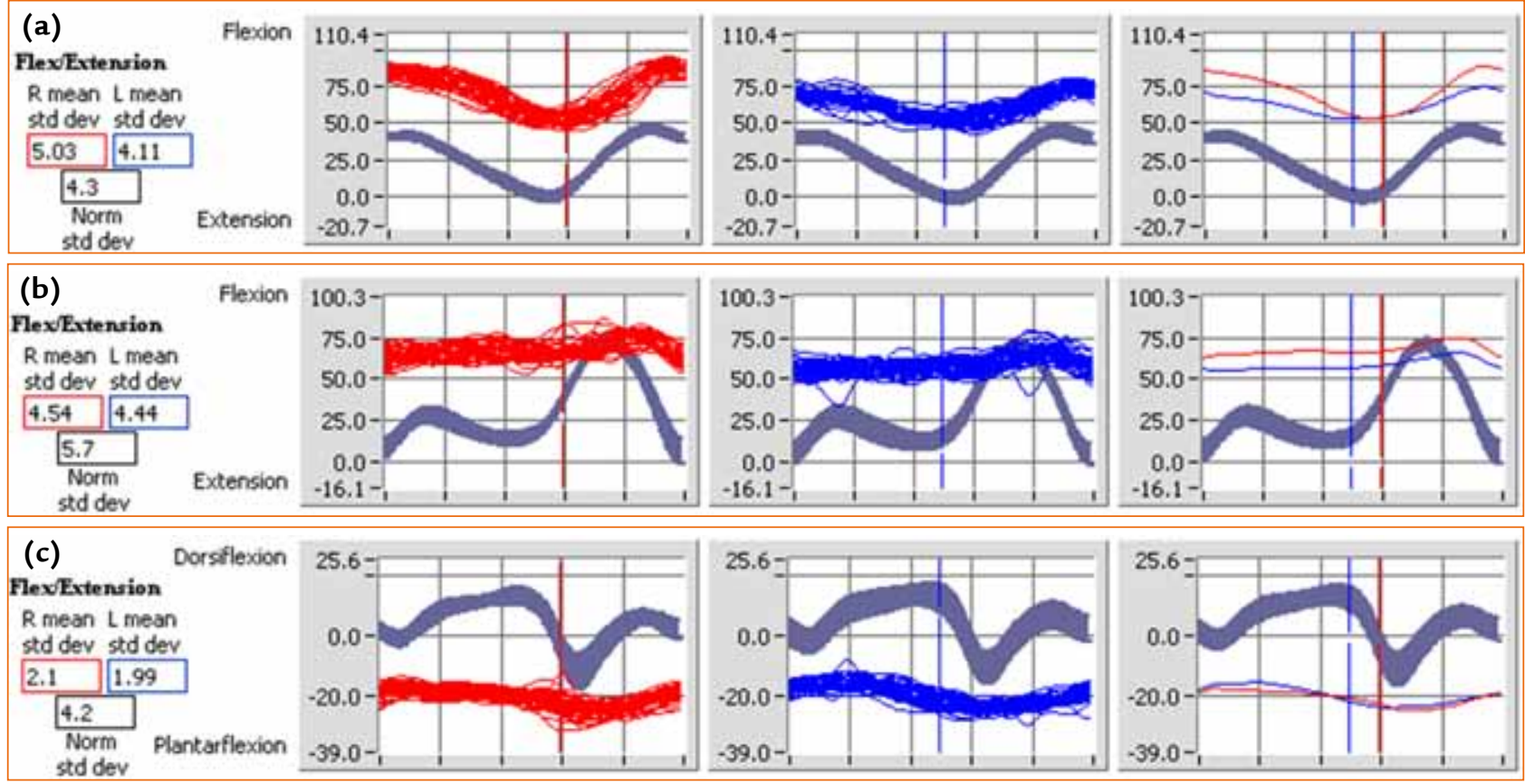

Şekil 9. a-c. Diastrofik displazili bir olgunun kalça (a), diz (b) ve ayak bileği (c) kinematik grafileri. Üç eklemde de basma ve salınım fazında yetersiz eklem hareket açıklığı ve fleksiyon kontraktürleri gözlenmektedir. 


\section{SPONDILOEPIFIZYAL DISPLAZI KONJENITA}

Spondiloepifizyal displazi konjenita, kromozom 12'de yer alan Tip 2 kollajen anomalisi sonucu gelişen bir hastalıktır. Omurga tutulumu sonucu hem gövde hem de ekstremite boyu kısalmıştır. Kalça ekleminde sıklıkla koksa vara deformitesi gözlenir. Hastalığın ağırlığı ile varus deformitesi arasında ilişki olduğu düşünülmektedir. ${ }^{[1,14]}$ Eğer varus deformitesi ileri düzeyde ise bu deformiteye sıklıkla fleksiyon kontraktürü ve retroversiyon eşlik eder. Hastalar sıklıkla kontraktürü tolere edebilmek için gövde ve başı geride tutarak mobilize olurlar. Diz ekleminde genu valgum ve femoral eksternal tosiyona eşlik eden tibial internal torisyon sıktır (Şekil 10, 11).

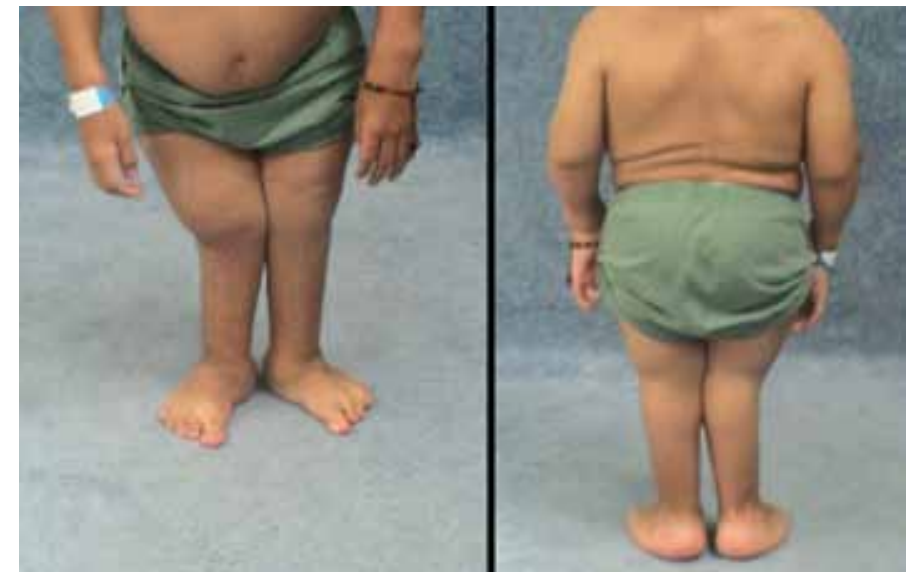

Şekil 10. Spondiloepifizyal displazi konjenita olgusu.

(a)

FlexExtension

$R$ mean $L$ mean std dev std dev

3

4.23

Norm

Abd/Adduction

$R$ mean $L$ mean

std dev std dev

2.432 .44

2.93

Norm std dov

Abouction

Extension

Adduction

(b)

Flex/Extension

$R$ mean L mean

std dev std dev

6.174 .55

5.2

Norm

std dev

\section{Varue/Valgus}

$R$ mean $L$ mean

stid dev std dev

$1.99 \quad 2.17$

\subsection{2}

std dev
Flexion
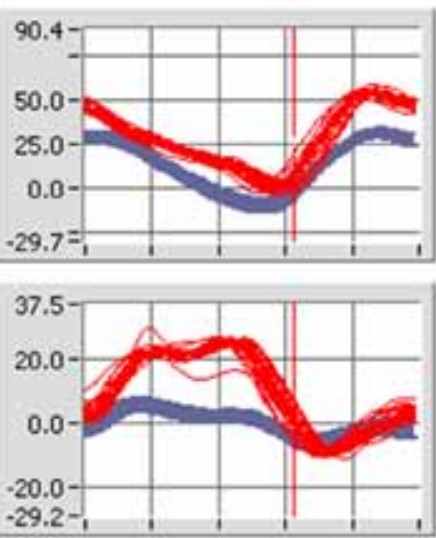

$-29.2-$
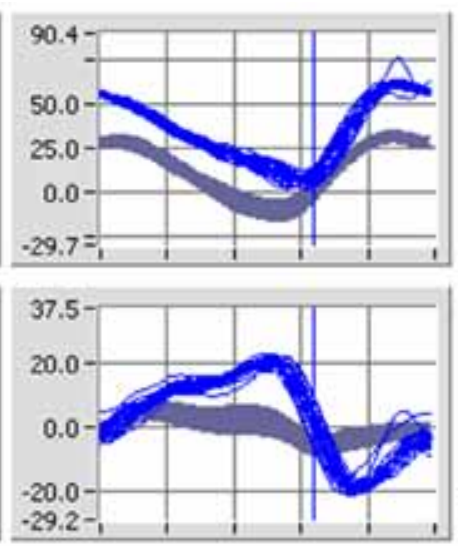

$-29.2-1, \ldots, \ldots$
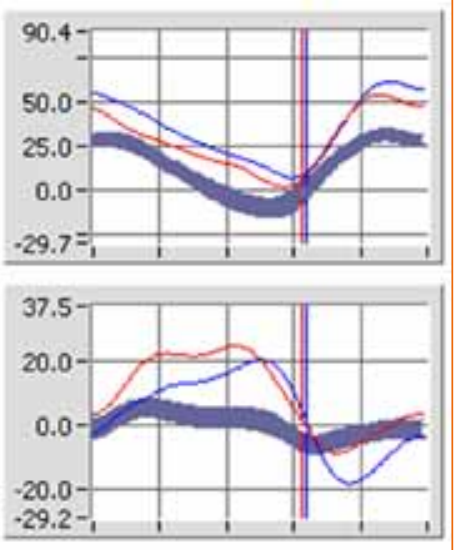

$-29.2$
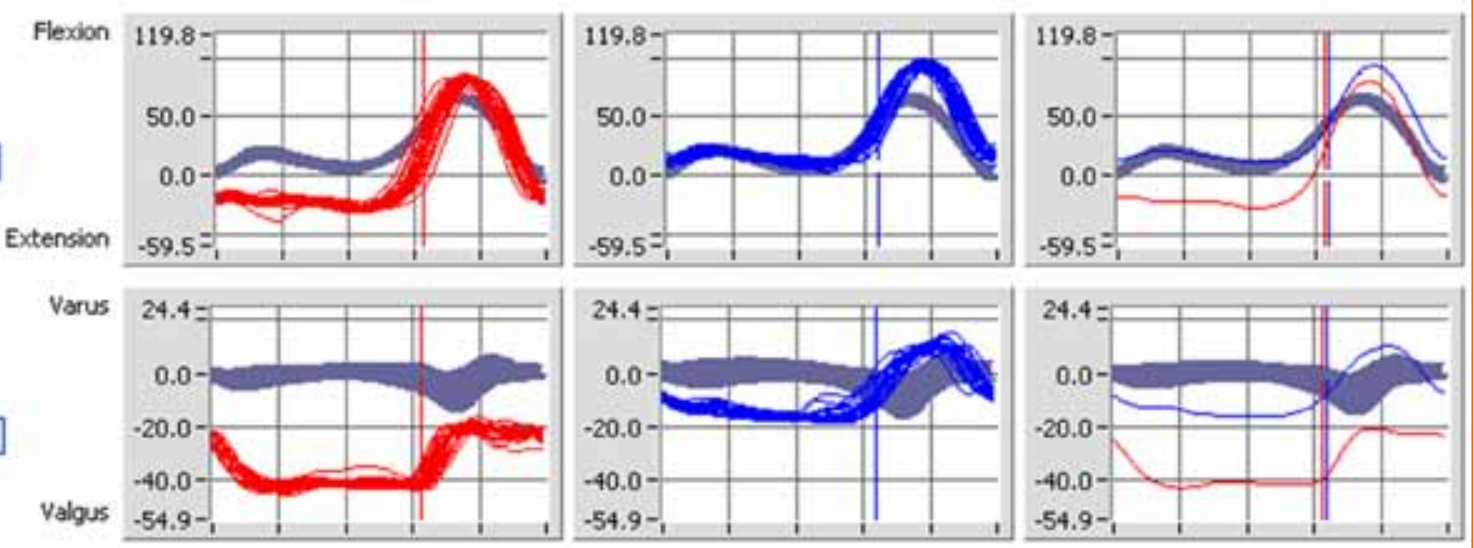

Şekil 11. a, b. Aynı olgunun kalça ve diz kinematik grafileri. Koksa vara deformitesine sekonder basma fazında kalça adduksiyonunda artış (a) ve sağ diz eklemindeki deformite nedeni ile artmış ekstansiyon ve valgus açılanması (b) gözlenmektedir. 


\section{MULTiPL EPIFIZYEL DISPLAZi}

Heterojen bir hastalık grubudur. Her ne kadar mutasyonlar birçok hastada 19. kromozomda yeralan COMP matriks glikoproteinini kodlayan genden kaynaklansa da, Tip 9 kollajende yer alan alfa 2 liflerinin yapısal bozukluğu, matrilin-3 defekti ve transport protein mutasyonlarının da etken olabileceği gösterilmiştir. ${ }^{[1,15-17]}$
Hastalar genellikle juvenil dönemde, alt ekstremite kaynaklı eklem ağrıları, eklem hareket genişliğinde azalma, yürüyüş bozuklukları, dizin rotasyonel veya açısal deformiteleri nedeni ile doktora başvururlar. ${ }^{[1,18]}$ Multipl epifizyel displazi olgularında diz valgus deformitesi sıklıkla gözlenir. Buna diz ve dirsek fleksiyon kontraktürü eşlik edebilir. Semptomların ortaya çıkması erişkin döneme kadar uzanabilir (Şekil 12, 13).

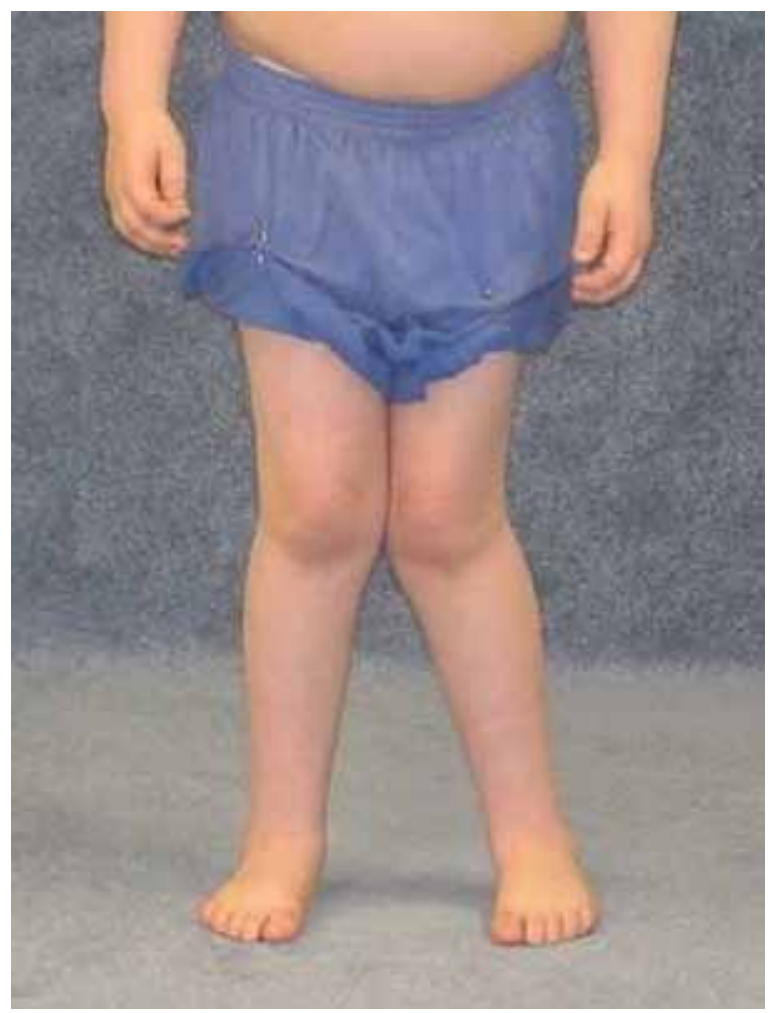

Şekil 12. Multipl epifizyel displazili bir olguda solda daha belirgin olmak üzere diz valgus deformitesi.

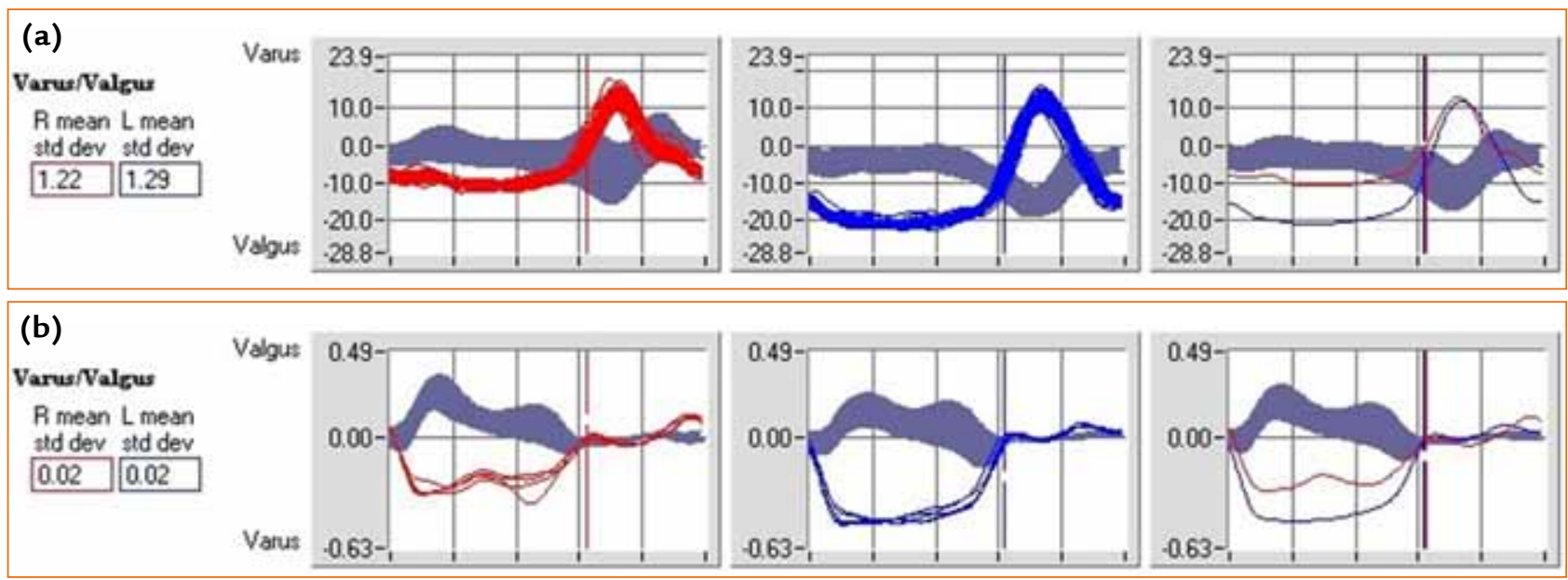

Şekil 13. a, b. Aynı olgunun diz kinematik ve kinetik grafileri: Solda daha belirgin olmak üzere her iki diz basma fazında artmış valgus açılanmasına (a) sekonder, artmış internal diz varus momenti (b) gözlenmektedir. 
İskelet displazilerine bağlı gelişen deformiteler çok fazla çeşitlilik göstermektedir. Üç boyutlu hareket analizi bu hasta grubunda deformitelerin değerlendirilmesinde yardımcı bir araç olarak görülmektedir. Bu konuda yapılacak öncü çalışmalar, hem iskelet displazilerinin neden olduğu deformitelerin yarattığı hareket paternlerinin değerlendirilmesinde hem de tedavinin iyileştirilmesinde yardımcı olacaktır.

\section{KAYNAKLAR}

1. Sponseller PD, Ain MC. The Skeletal Dysplasias. In: Morrissy RT, Wienstein SL, editors. Lovell and Winter's Pediatric Orthopaedics, 6th ed. Philadelphia: Lippincott Williams \& Wilkins; 2006. p.205-50.

2. Beighton $P$, Giedion ZA, Gorlin R, Hall J, Horton B, Kozlowski K, Lachman R, Langer LO, Maroteaux P, Poznanski A, et al. International classification of osteochondrodysplasias. International Working Group on Constitutional Diseases of Bone. Am J Med Genet 1992;44(2):223-9.

3. Dhawale AA, Church C, Henley J, Holmes L Jr, Thacker MM, Mackenzie WG, Miller F. Gait pattern and lower extremity alignment in children with Morquio syndrome. J Pediatr Orthop B 2013;22(1):59-62. CrossRef

4. Dietz FR, Mathews KD. Update on the genetic bases of disorders with orthopaedic manifestations. J Bone joint Surg Am 1996;78(10):1583-98.

5. Hall J G. The natural history of achondroplasia. Basic Life Sci 1988;48:3-9.

6. Wynne-Davies R, Walsh WK, Gormley J. Achondroplasia and hypochondroplasia. Clinical variation and spinal stenosis. J Bone joint Surg Br 1981;63B(4):508-15.

7. Nehme AM, Riseborough EJ, Tredwell SJ. Skeletal growth and development of the achondroplastic dwarf. Clin Orthop Relat Res 1976;(116):8-23.
8. Inan M, Thacker M, Church C, Miller F, Mackenzie WG, Conklin D. Dynamic lower extremity alignment in children with achondroplasia. J Pediatr Orthop 2006;26(4):526-9.

9. Deere M, Sanford T, Francomano CA, Daniels K, Hecht JT. Identification of nine novel mutations in cartilage oligomeric matrix protein in patients with pseudoachondroplasia and multiple epiphyseal dysplasia. Am J Med Genet 1999;85(5):486-90.

10. Ferguson HL, Deere M, Evans R, Rotta J, Hall JG, Hecht JT. Mosaicism in pseudoachondroplasia. Am J Med Genet 1997;70(3):287-91.

11. Gaebe G, Kruse R, Rogers K, MacKenzie WG, Holmes L. Dynamic Lower Extremity Deformity in Children with Pseudoachondroplasia. J Pediatr Orthop. [under review]

12. Hollister DW, Lachman RS. Diastrophic Dwarfism. Clin Orthop Relat Res 1976;(114):61-9.

13. Weiner DS, Jonah D, Kopits S. The 3-dimensional configuration of the typical foot and ankle in diastrophic dysplasia. J Pediatr Orthop 2008;28(1):60-7.

14. Wynne-Davies R, Hall C. Two clinical variants of spondyloepiphysial dysplasia congenita. J Bone Joint Surg $\mathrm{Br}$ 1982;64(4):435-41.

15. Briggs MD, Chapman KL. Pseudoachondroplasia and multiple epiphyseal dysplasia: mutation review, molecular interactions, and genotype to phenotype correlations. Hum Mutat 2002;19(5):465-78.

16. van Mourik JB, Hamel BC, Mariman EC. A large family with multiple epiphyseal dysplasia linked to COL9A2 gene. Am J Med Genet 1998;77(3):234-40.

17. Mäkitie O, Mortier GR, Czarny-Ratajczak M, Wright MJ, Suri M, Rogala P, Freund M, Jackson GC, Jakkula E, AlaKokko L, Briggs MD, Cole WG. Clinical and radiographic findings in multiple epiphyseal dysplasia caused by MATN3 mutations: description of 12 patients. Am J Med Genet A 2004; $125 \mathrm{~A}(3): 278-84$.

18. Jacobs PA. Dysplasia epiphysialis multiplex. Clin Orthop Relat Res 1968;58:117-28. 